\title{
The relationship between the habits of a currently used system and the acceptance of a new system*
}

\author{
Woong-Kyu Lee** Hyo-Jung Kim*** \\ I . Introduction \\ <목 차> \\ П. Literature Review \\ V. Data Analysis \\ III. Hypotheses and Research Model \\ VI. Conclusion \\ IV. Method \\ References \\ $<$ Abstract $>$
}

\section{Introductin}

According to the theories of information technology (IT) adoption such as the technology acceptance model (TAM) (Davis, 1989; Davis et al., 1989), the adoption of a new system is determined by reasoning-based judgments such as beliefs of, attitude toward, and intention of the new system. However, in most cases, the adoption of a new system may be influenced by the systems that so far have been or currently are used, in addition to the perceptions of the new system. For example, the acceptance of a new word processor may not be independent of the system that has been so far or is currently being used.
More specifically, the acceptance of a new system may be influenced by the unconscious habits of using the current system as well as their judgments of the new system. In general, routine behaviors are controlled by habits while new and important behaviors are guided by conscious judgments (Fishbein and Ajzen, 1975; 2010; Triandis, 1980). While the adoption of new systems is considered a relatively new behavior, the continuous use of the current system may be considered a routine behavior. Thus, habit is one of the most influential factors for governing the continuous use of the current system (Kim, 2009; Kim and Malhotra, 2005; Limayem et al., 2007; Oritz de Guinea and Makus, 2009). This implies

* This research was supported by the Daegu University Research Grant, 20080350

** Woong-Kyu Lee, Department of Business Administration, Daegu University, woong3041@empal.com *** Hyo-Jung Kim, Keymyung University, Kimhj95@kmu.ac.kr 
that habits in using the current system may influence the adoption of a new system.

Interestingly, the effects of habits in relation to the current system on the adoption of new systems may be negative in some cases but positive in other cases. To habitual users of the current system, the switch to a new system may entail relatively high costs such as uncertainties of the new system, learning the new system and transforming the accumulated files into the new format. On the other hand, habitual users may have relatively rich experience in using the current system, which can provide familiarity and sufficient expertise for evaluating and accepting the new system (Lee 2012). For example, if a new word processor is given to somebody who is habituated to a specific word processor, s/he may hesitate to use a new one since s/he would not want to experience anxiety of uncertainties and tiresomeness in learning how to use it and transforming the current system's file format into the new one, which may negatively influence the adoption of the new system. Nevertheless, s/he may have enough familiarity and expertise for evaluating the usefulness and ease-of-use of the new system, which will yield positive effects.

This study suggested the following research questions.

R1: Do the habits in relation to using the current system influence the adoption of a new system positively, negatively or both?

R2: If the effects may be both positive and negative, which factors can determine the direction?

For answering the research questions, this study suggested hypotheses, which explain the relationships between the habits regarding the current system and the acceptance of a new system. These relationships may be negative without any conditions, but if direct experience with using the new system is given, they may be positive. In order to show the validity of these hypotheses, 168 Korean university students, who were believed to be habitually using a word-processor or a suite and did not have experience with Google Docs, were grouped into two. To one group, Google Docs was only introduced while the students in the other group directly used it in addition to the introduction. Then, the relationships in our hypotheses were measured by surveying all the participants and analyzed by the partial least squares (PLS) approach.

\section{Literature Review}

Much research of experience in the uses of information systems(IS) have considered experiences as a factor for influencing the adoption of a new IT. Hence, most studies were based on well-known IT acceptance frameworks such as the TAM (Davis 1989; Davis et al, 1989) and theory of planned behavior (TPB) (Ajzen, 1991) and theoretically more advanced models, 
which can also explain the continuity, such as unified theory of acceptance and use of technology (UTATU) (Venkatesh et al., 2003) and expectation-confirmation theory (ECT) (Bhattacherjee, 2001). Traditionally the studies of experience in the studies of IT acceptance were to analyze the strength between intention and usage by the comparison between experienced and inexperienced users (Taylor and Todd, 1995; Gefen et al, 2003), pre and post implementation (Szajna 1996), and adopters and users (Karahanna et al, 1999), while other studies adopted longitudinal approach and observed the change of beliefs as time passed (ex: Bhatacherjee and Premkumar, 2004; Davis and Venkatesh, 2004; Venkatesh and Davis, 2000; Venkatesh et al., 2003; Venkatesh et al., 2012). In spite of some differences in methodology, the main objective of these studies was to show that experiences would resolve uncertainties and improve understanding in beliefs of a new system.

Whereas experiences were studied in the context of IT adoption, main focus in habit studies was on the continuous use in post-adoption. Habits are defined as learned sequences of acts that have become automatic responses given specific cues for the acquisition of certain goals or end-states (Verplanken, 2006; Verplanken and Orbell, 2003). Thus habits may guide routine behaviors that are performed without consciousness (Ouellette and Wood, 1998; Triandis, 1980; Verplanken, 2006; Verplanken and Orbell, 2003). The use of currently accepted systems also can be considered a routine behavior. The users would focus only on the jobs that should be done by the system rather than the evaluations of the system. Moreover, most users may become familiar with and have expertise with the system by repeatedly using it. Thus, their active use of the system would be dependent on unconscious habits.

Previous studies also agreed that habit should be considered as one of principal factors for maintaining the use of current system (Bhattacherjee and Barfa, 2011; Kim, 2009; Limayem et al., 2007; Ortiz de Guinea and Markus, 2009, Venkatesh et al., 2012). For example, Bhattacherjee and Barfa (2011) suggested a research model for explaining continuous uses which improved ECT by adding habit as a predictor of usage as well as a moderator between intention and usage. Kim (2009) explained the relationships between usages by habit, adopting the theory of memory processing and especially showed that habit have both proximal and distal effects. Limayem et al (2007) also extended ECT by focusing on the antecedents of habit and adopting a new antecedent of habit, comprehensive of usage, in addition to as a moderator between intention and usage. Oritz de Guinea and Markus (2001) theoretically discussed the roles of habit as a driver of continuous use including. Venkatesh et al. (2012) suggested an extended version of UTAUT for the acceptance and use of IT by including habit as a predictor of intention. As seen 
so far, while the effect of habit on the continuance of system was studied in very many ways, the relationship between habit and IT acceptance was not identified and analyzed. Moreover, the effect of the habit in a current used system on the acceptance of a new system have not been conducted yet.

\section{Hypotheses and Research Model}

The users who have used only a specific system for a long time may have status a quo bias, that is, an irrational preference for continuing to use the current system to accepting a new system (Kim and Kankanhalli, 2009). Habits of a specific system imply the repetitive usages of the same system under the control of unconsciousness rather than conscious intention (Kim, 2009; Limayem et al, 2007; Venkatesh et al, 2012). Thus, habitual users also may have a status quo bias and tend to be being 'locked-in' to the current used system), which means that is not easy for habitual users to avoid switching costs (Shapiro and Varian, 1999). Switching costs refer to the expected costs of switching from a current system to an alternative one in order to ensure compatibility between both systems(Kim et al, 2006; Ray et al, 2012). Therefore, habit strength of using a system would be a positive factor for the continuance of the current used system but a negative factor for the acceptance of a new system
(Lee 2012).

Specifically, the switching costs from habit would influence two principal beliefs for using a new system: usefulness, the degree to which a person believes that using a particular system would enhance his or her job performance, and ease of use, the degree to which a person believes that using a particular system would be free of effort (Davis, 1989; Davis et al., 1989).

One of such switching costs is uncertainty costs, representing the psychological uncertainty or perception of risk associated with the new system, which are arise when performance or functions of a new system is perceived less than expected (Kim and Kankanhalli, 2009; Ray et al, 2012). Given a new system that has never been used, habitual users who have accustomed to a system are not sure that this new system can provide similar usefulness to the current used system. Especially, if they have been satisfied with the current system, their anxiety of usefulness for a new system would be stronger. As previous studies pointed out, satisfaction is one of principal conditions for the formulation of habit (Limayem et al, 2007). Therefore, the stronger habit of the current system, the less sure and the more anxious about usefulness of a new system.

Hypothesis 1: The strength of habit in relation to the current system will negatively influence the perceived usefulness of a new system.

In addition to uncertainty costs, transfer costs and learning costs also influence the judgment for 
the beliefs of IT acceptance. Transfer costs refer costs which are required to end the current system and start a new system and learning costs are the time and effort needed to adapt to a new provider (Jones et al, 2002; Ray et al, 2012). For example, files stored in the format of current system should be transformed into the new ones compatible with a new system. In order to use a new system, users should learn how to use it. To habitual users, these tasks may be perceived as troublesome and tiresome.

Hypothesis 2: The strength of habit in relation to the current system will negatively influence the perceived ease-of-use of a new system.

The habitual uses of the current system, in addition to switching costs, may imply rich experiences of the system which would easily lead to familiarity and expertise with new systems (Lee 2012). Generally, most systems, if they have the same or similar purposes, also have similar functions and interfaces although they are somewhat different from each other. For example, all word processors have similar functions and user interfaces. This means that habitual users may have sufficient familiarity and expertise to evaluate the usefulness and ease of use of new systems with minimal switching costs. Therefore, whereas lock-in and switching costs still operate, if the proper conditions are provided, the role of habit can be switched from a negative one into a positive one.

One of the reasons why switching costs are involved in habit is that both amount and reliability of information about a new system is less than the current system. Thus, direct experience of using a new system is believed to be a condition for changing the role of habit. According to the attitude-behavior theories in psychology, direct experience with an attitude object implies not only more information about the object which may be available but also more reliable and salient information through behavioral experiences than indirect or no experiences (Fazio and Zanna 1981). The previous studies also showed that the effects of beliefs through direct experience of a new system would be stronger than indirect experiences or no experience (ex: Gefen et al., 2003; Igbaria and Iivari, 1995; Karahanna et al, 1999; Szajna, 1996; Taylor and Todd, 1995). Moreover, some studies showed that direct experiences help to resolve users' perceived uncertainties of usefulness and ease of use (Bhattacherjee and Premkumar, 2004; Venkatesh et al, 2011).

In case of our study, direct experience of using a new system would help to have more reliable and stable information about functions and performance. This information joined with expertise based on the rich experiences of the current system would resolve anxiety and improve sureness for usefulness. Similarly, direct experiences itself would be easily accustomed to using a new system, which would positively influence ease of use. 


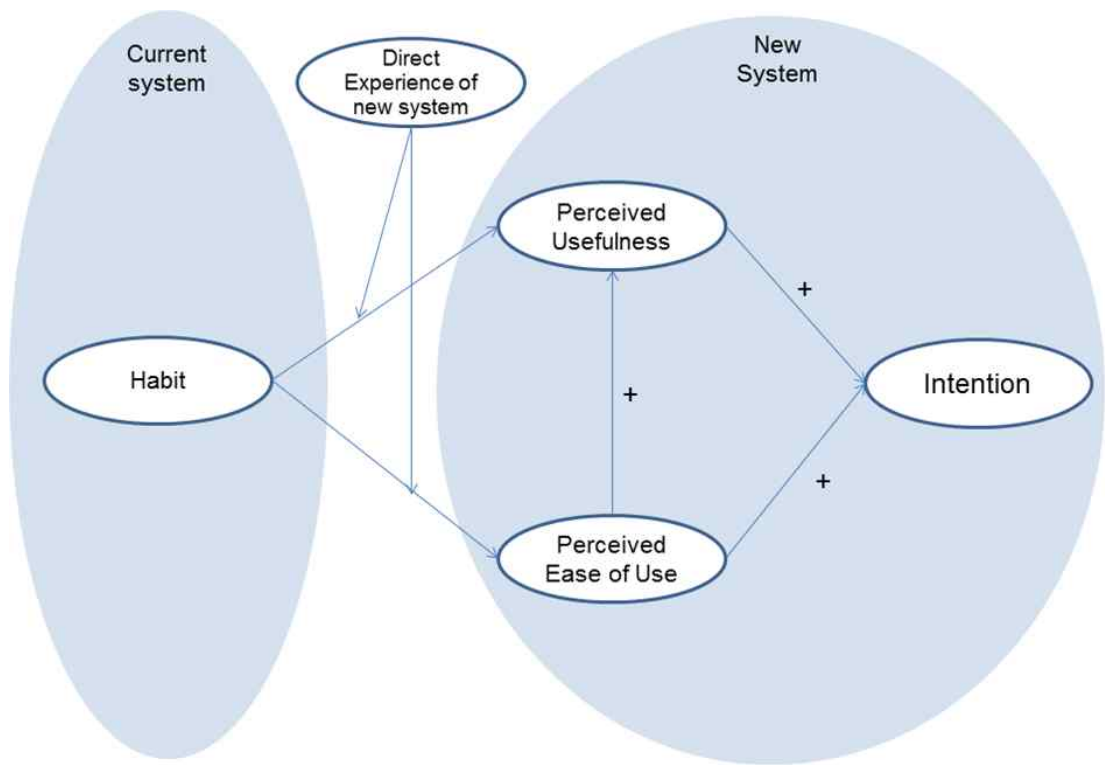

<Figure 1> Research Model

Hypothesis 3: Given an opportunity for direct experience in using a new system, habit will positively influence the usefulness of the new system.

Hypothesis 4: Given an opportunity for direct experience in using a new system, habit will positively influence the ease-of-use of the new system.

The hypotheses that have been suggested so far can be summarized into the following research model as shown in Figure 1.

Our research model consists of the habits regarding the currently used system and the acceptance of a new system. The direction of the relationship between the two parts can vary due to direct experience with the new system. If the experience is given, the direction would be positive, but if not, it would be negative.

\section{Method}

The participants, 168 undergraduate students at the University of Daegu and the University of Keimyung, Korea, had enough experience in using more than one specific word-processor or suite but did not have any experience in Google Docs. The profile of the participants is shown in Table1.

For all participants, the strength of the habit for the word-processor that they had mostly used was measured by the Self-Report Habit Index (SRHI) (Verplanken and Orbel, 2003). Then, the participants were randomly classified into two groups. To each group, Google Docs was simply introduced by an explanation of the main features including not only how to use it (it is very similar to the other common word-processors or suites) 
$<$ Table 1> Profile of the participants

\begin{tabular}{|c|c|c|c|}
\hline \multicolumn{2}{|c|}{ Variable } & Inexperienced & Experienced \\
\cline { 2 - 4 } & Male & Frequency (\%) & Frequency (\%) \\
\cline { 2 - 4 } & Female & $55(61.1)$ & $41(52.6)$ \\
\cline { 2 - 4 } Gender & SUM & $35(38.9)$ & $37(47.4)$ \\
\hline \multirow{4}{*}{$\begin{array}{c}\text { Currently most used } \\
\text { suite }\end{array}$} & Hancom Office & $90(100)$ & $78(100)$ \\
\cline { 2 - 4 } & MS Office & $53(92.2)$ & $72(92.4)$ \\
\cline { 2 - 4 } & Others & $5(5.6)$ & $3(3.8)$ \\
\hline \multirow{4}{*}{$\begin{array}{c}\text { Experience in using } \\
\text { the current system }\end{array}$} & SUM & $90(100)$ & $3(3.8)$ \\
\cline { 2 - 4 } & Below 5 years & $22(26.5)$ & $78(100)$ \\
\cline { 2 - 4 } & Above 10 years & $32(38.6)$ & $27(34.7)$ \\
\cline { 2 - 4 } & SUM & $36(34.9)$ & $32(40.9)$ \\
\hline
\end{tabular}

$<$ Table 2> Items for measurement

\begin{tabular}{|c|c|c|}
\hline Construct & Item & Scale \\
\hline \multirow{7}{*}{ Habit } & HA1 & I use [the current system] automatically. \\
\hline & HA2 & I use [the current system] without having to consciously remember. \\
\hline & HA3 & I use [the current system] without thinking. \\
\hline & HA4 & I would find it hard not to use [the current system]. \\
\hline & HA5 & If I do not use [the current system], that makes me feel weird. \\
\hline & HA6 & I have no need to think about using [the current system]. \\
\hline & HA7 & I have been using [the current system] for a long time. \\
\hline \multirow{4}{*}{ Intention } & INT1 & I would use [the new system] hereafter. \\
\hline & INT2 & I would continuously use [the new system], if possible. \\
\hline & INT3 & I would use [the new system] consistently. \\
\hline & INT4 & I would recommend the use of [the new system] to others. \\
\hline \multirow{6}{*}{ Ease of use } & EU1 & It looks easy to operate [the new system]. \\
\hline & EU2 & I find it easy to get [the new system] to do what I want to do. \\
\hline & EU3 & It is easy to be familiar with [the new system]. \\
\hline & EU4 & Using [the new system] would not require a lot of effort. \\
\hline & EU5 & It is easy to remember how to use [the new system]. \\
\hline & EU6 & Overall, it is easy to use [the new system]. \\
\hline \multirow{6}{*}{ Usefulness } & PU1 & Using [the new system] would improve the efficiency of my job. \\
\hline & PU2 & Using [the new system] would increase my productivity. \\
\hline & PU3 & Using [the new system] would increase my job performance. \\
\hline & PU4 & Using [the new system] would give me greater control over my work. \\
\hline & PU5 & Using [the new system] would make it easier to do my job. \\
\hline & PU6 & Overall, I find [the new system] useful in my job. \\
\hline
\end{tabular}


but also some different functions such as cooperation with other users and file management on the Internet. However, in addition to the introduction, one group had direct experience in using Google Docs, which included not only making documents but also sharing them with others, for about one hour, whereas the other group was not given that experience. After the introduction and the experience (only for one of the groups), for both groups, the acceptance of the new system, Google Docs, was evaluated by instruments for TAM-related variables such as usefulness, ease of use, and intention (Davis, 1989; Davis et al., 1989). The instruments adopted in this study were as shown in Table 2.

\section{Data Analysis}

Data analysis was conducted via the partial least squares (PLS) method, which was utilized to evaluate the psychometric properties of all scales and subsequently to test the structural relationships proposed in the model (Gefen et al., 2003).

Convergent validity is the extent to which the items of a scale that are theoretically related are also related in reality. Convergent validity was assessed via loadings of the measurements with composite reliability and average variance extracted (AVE) (Limayem et al., 2007). As shown in Appendices 1 and 2, for both groups, the loadings of items in all constructs were greater

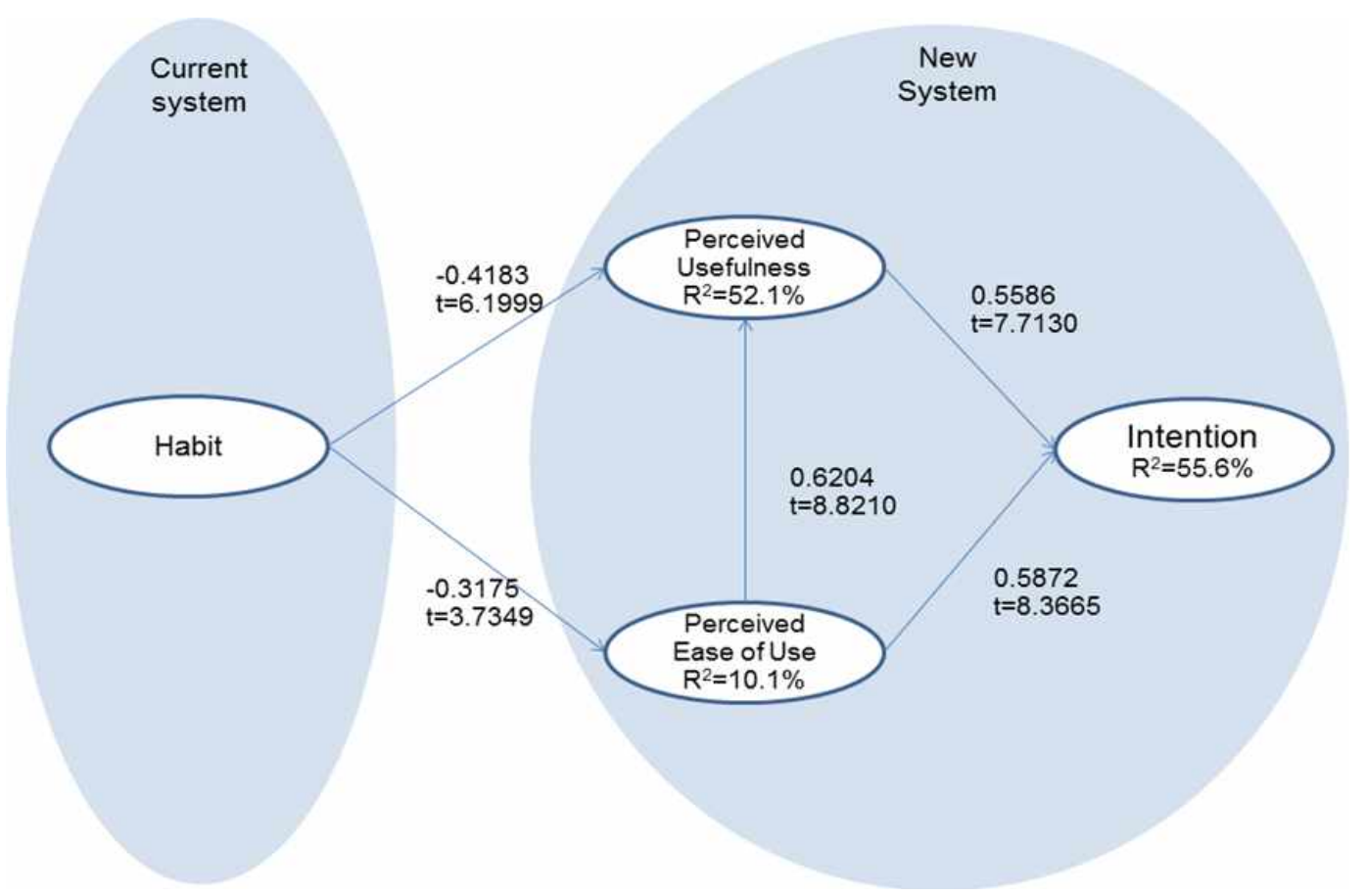

$<$ Figure 2> Path analysis for the inexperienced group 
than 0.7 (statistically significant), and the scores of AVE composite reliability for all constructs were also greater than 0.6 and 0.7 , which are the established criteria for each of the indices (Gefen et al., 2003). Thus, the measurements in this study could be said to have convergent validity.

Discriminant validity is demonstrated in PLS when each loading is higher on its corresponding construct than on other constructs in the model, and the square root of the average variance extracted is larger than the inter-construct correlations (Gefen and Straub 2005). Similar to the case of convergent validity, for both groups, the scores for the square roots of the AVE values of all constructs were greater than the correlations with other constructs, as shown in Appendices 3 and 4, and the loadings of all constructs were greater than the cross-loadings, as shown in Appendices 5 and 6. Thus, in addition to convergent validity, discriminant validity was revealed by the measurements of this study.

The results of path analysis from PLS are shown in Figures 2 and 3. The path coefficients and their t-values were generated from PLS bootstrapping. As shown in Figure 2, the group that did not have direct experience with Google Docs had an $\mathrm{R}^{2}$ value donga intention of $55.6 \%$; the corresponding values for PU and PEOU were $52.1 \%$ and $10.1 \%$, respectively. Similarly, the experienced group showed $\mathrm{R}^{2}$ values for intention, PU, and PEOU of $35.6 \%, 23.8 \%$, and $10 \%$, respectively, as shown in Figure 3 . Thus,

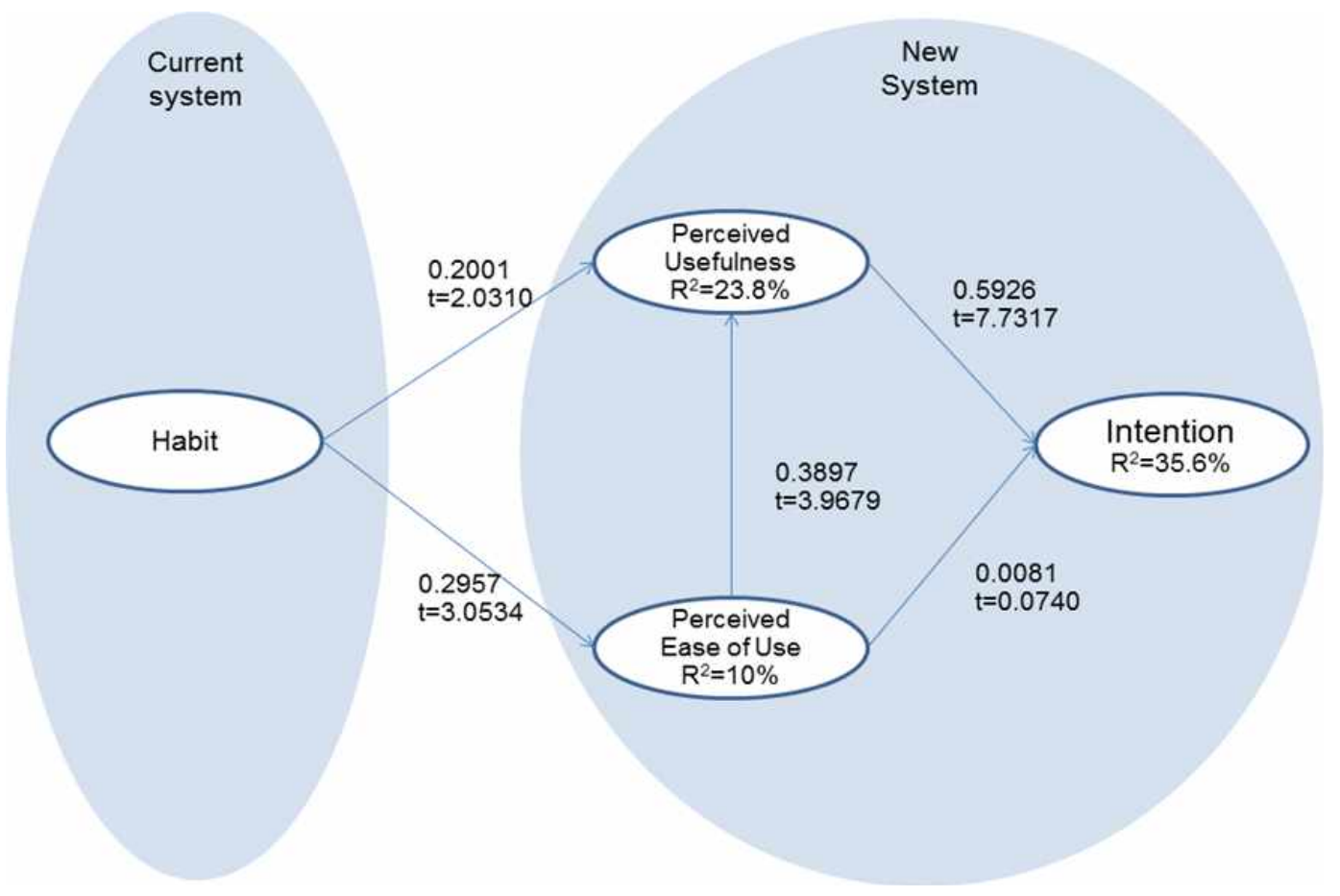

$<$ Figure 3> Path analysis for the experienced group 
both groups evinced substantive explanatory power of over $10 \%$, as suggested by Falk and Miller (1992).

As shown in Figure 3, for the inexperienced group, all TAM-related relationships, viz., PU-intention, PEOU-intention, and PEOU-PU, were positive with significance levels of less than 0.01 . However, in the experienced group as shown in Figure 3, PEOU-PU was not supported, while two relationships, PU-intention and PEOU-PU, were positive with significance levels of less than 0.01 , which were consistent with previous studies (e.g., Davis et al., 1989; Szanjna, 1996; Gefen and Strout, 2000). Thus, TAM-related relationships were still valid in our setting.

Figures 3 and 4 also showed that the hypotheses were all supported. While both relationships, viz., habit-PU and habit-PEOU, were negative with significance levels of less than 0.001 for the inexperienced group, habit-PEOU and habit-PU were positive for the experienced group although the significance level of habit-PU was less than 0.05 .

\section{Conclusion}

The objective of this study was to answer two research questions: whether a relationship may exist between the habits in relation to using the current system and the adoption of a new system and if then, which factors can determine the direction. For answers to the two research questions, this study suggested hypotheses whereby the relationships between the habits regarding the current system and the new system's usefulness and ease of use may change due to direct experience with the new system. That is, if experience with the new system is not given, the relationship would be negative, but if such experience is given, it may be positive. For showing validity, Google Docs was introduced to 168 Korean university students who had no experience with that system. They were randomly classified into two groups. One group had direct experience with using Google Docs but not the other group. In terms of results, the experienced group showed a negative relationship between habits and beliefs in the new system but the inexperienced group showed a positive relationship.

This study provided the following theoretical implications. First, habit was shown to be a main factor of the acceptance of a new system. Although previous studies attempted to show the roles of habit in IS uses in very many ways, the target was to find the mechanism or factors for determining the continuous uses. However, this study identified and analyzed the habit of a current system for explaining the acceptance of a new system. That is, while the object of habit in this study was the current used system, the main target was the effects of habit on the acceptance of a new system.

Second, the dual roles of habit were analyzed. 
In most studies, habit was considered a driver of routinized usages under the control of unconsciousness (ex: Kim 2009; Limayem et al, 2007; Venkatesh et al, 2012), which would be believed to have the negative effects on the acceptance of a new system. However, this study found out the other side of habit, that is, expertise and knowledge of a system from rich experiences which can positively influence the acceptance of a new system if direct experience is give.

Third, the acceptance of a new system may be complementary to the current used system. The actions that engender habits concerning IT use cannot easily be forgotten since they are known to be stored as implicit memory that can be stored for a relatively long time independent of consciousness (Kim, 2009; Myers, 2007). For example, habitual users of MS-Word Office will unconsciously continue to use MS-Word although they have favorable attitudes toward and accept Google Docs.

This study can provide practical implications to system vendors or service provides as follows: First, the importance of the systems which are mostly used in market should be re-emphasized. As seen in the first theoretical implication, users' attitude toward new system was not free from the current system. Since any users have some status quo bias, more or less, drastic changes in a new released system may make users be hesitate to accept the system. Furthermore, some users would be hostile and repulsive to revolutionary changes and resist new systems (Kim and
Kankanhalli, 2009). While the revolution of new system is very important for competitive advantages, vendors or service providers should also consider the functions and performance or how to use of the current used system.

Second, the importance of direct experience was also confirmed. As seen in this study the opportunity for experience can help users who have habit of the current system to resolve anxieties and uncertainties of a new system. Thus, vendors or service providers should develop managerial methods for providing more opportunities for using a system such as more aggressive release of beta version.

In spite of the implications, this study has had some limitations in the control of the experiment. First of all, there is no objective evidence that experience with a new system is enough to lower the switching cost although it was empirically demonstrated. Similarly, we cannot establish that the results of our study may be due to differences between the two groups in the switching cost rather than the opportunity of experience. While most participants were students who had enough experience with current word-processing systems, there were some problems in the control of the experiment.

The results of this study can suggest new research topics. First, a research model including the switching cost of the currently used system can be suggested. One of the main assumptions in this study was that the habits regarding the currently used system would cause a switching 
cost. Nevertheless, this study did not measure the switching cost although measurements were suggested by previous research (Kim et al., 2004; Ray et al., 2012). The inclusion of the switching cost in the research model would yield more interesting implications.

Second, more diverse moderating variables can be applied to our research framework. The habits concerning the currently used system may have different effects compared to other factors other than direct experience with the new system. For example, different types of IT may have also different effects on the acceptance of the new system. The duration or expertise regarding current systems may be an alternative for the moderating variables.

\section{References}

Azjen, I., "The Theory of Planned Behavior", Organizational Behavior and Human Decision Processes, Vol. 50, 1991, pp. 179-211

Bhattacherjee, A., "Understanding Information Systems Continuance: an ExpectationConfirmation Model", MIS Quarterly, Vol. 25, No. 3, 2001, pp. 351-370.

Bhattacherjee, A. and Barfa, A., "Information Technology Continuance Research: Current State and Future Directions", Asia Pacific Journal of Information Systems, Vol. 21, No. 2, 2011, pp. 1-18.
Bhattacherjee, A. and Premkumar, G., "Understanding Changes in Belief and Attitude toward Information Technology Usage: A Theoretical Model and Longitudinal Test", MIS Quarterly, Vol. 28, No. 2, pp. 2004, 229-254,

Davis, F. D., "Perceived Usefulness, Perceived Ease of Use, and User Acceptance of Information Technology", MIS Quarterly, Vol. 13, No. 3, 1989, pp. 319-340.

Davis, F. D., Bagozzi, R. P. and Warshaw, P. R., "User Acceptance of Computer Technology: a Comparison of Two Theoretical Models", Management Science, Vol. 35, No. 8, 1989, pp. 982-1003.

Davis, F. D. and Venkatesh, V., "Toward Preprototype User Acceptance Testing of New Information Systems: Implications for Software Project Management", IEEE Transactions on Engineering Management, Vol. 51, No. 1, 2004, pp. 31-46.

Falk, R. F. and Miller, N. B. , Primer for Soft Modeling, University of Akron Press, 1st edition, 1992,

Fazio, R. H. and Zanna, M. P., "Direct Experience and Attitude-Behavior Consistency", In Advances in Experimental Social Psychology (Berkowitz L, Eds), Vol. 14, 1981, pp. 161-202. 
Fishbein, M. and Ajzen, I. Belief, Predicting and Changing Behavior - The Reasoned Action Approach, NY: Psychology Press, NY., 2010.

Fishbein, M. and Ajzen, I., Attitude, Intention, and Behavior: an Introduction to Theory and Research, Reading. Addison-Wesley, MA., 1975.

Gefen, D., Karahanna, E. and Straub, D. W., "Inexperience and Experience with Online Stores: The Importance of TAM and Trust", IEEE Transactions on Engineering Management, Vol. 50, No. 3, 2003, pp. 307-321.

Gefen, D. and Straub, D. B., "A Practical Guide to Factorial Validity Using PLS-Graph: Tutorial and Annotated Example", Communications of the Association for Information Systems, Vol. 16, No. 5, 2005, pp. 91-109.

Igbaria, M. and Iivari, J., "The Effect of Self-efficacy on Computer Usage", Omega, Vol. 23, No. 6, 1995, pp. 587-605.

Jones, M. A., Mothersbaugh, D. L., and Beatty, S. E., "Why customers stay: Measuring the Underlying Dimensions of Services Switching Costs and Managing their Differential Strategic Outcomes", Journal of Business Research, Vol. 55, 2002, pp. 441-450.

Karahanna, E., Straub, D. W. and Chervany, N. L., "Information Technology Adoption across Time: A Cross-Sectional Comparison of Pre-Adoption and Post-Adoption Beliefs", MIS Quarterly, Vol. 23, No. 2, 1999, pp. 183-213.

Kim, H-W. and Kankanhalli, A.,"Investigating User Resistance to Information Systems Implementation: A Status Quo Bias Perspective", MIS Quarterly, Vol. 33, No. 3, 2009, pp. 567-582.

Kim, G., Shin, B. and Lee, H. G., "A Study of Factors that Affect User Intentions toward email Service Switching". Information \& Management", 43, 2006, pp. 884-993.

Kim, S. S., "The Integrative Framework of Technology Use: an Extension and Test", MIS Quarterly, Vol. 33, No. 3, 2009, pp. 513-537.

Kim, S. S. and Malhotra, N. K., "A Longitudinal Model of Continued IS Use: an Integrative View of Four Mechanisms underlying Postadoption Phenomena". Management Science, Vol. 51, No. 5, 2005, pp. 741-755.

Lee, W-K., "The Dual Effect of Habits in a Current Used System on the Acceptance of a New IT", in Proceedings of 2012 International Conference on Information Resource Management, August 2-6, Vienna, Austria, 2012.

Limayem, M, Hirt, S. G. and Cheung, C. M. K., "How Habit Limits th Predictive Power of Intention: The Case of Information 
Systems Continuance", MIS Quarterly, Vol. 31, No. 4, 2007, pp. 705-737.

Myers, D. G., Psychology (eighth edition), Worth Publishers, NY., 2007.

Oritz de Guinea, A. and Markus, M. L.,"Why Break the Habit of a Lifetime? Rethininking the Roles of Intention, Habit, and Emotion in Continuing Information Technology Use", MIS Quarterly, Vol. 33, No. 3, 2009, pp. 433-444.

Ouellette, J. and Wood, W., "Habit and Intention in Everyday Life: the Multiple Processes by which Past Behavior Predicts Future Behavior", Psychological Bulletin, Vol. 124, No. 1, 1998, pp. 54-74.

Ray, S., Kim, S. S., and Morris, J. G., "Online Users' Switching Costs: Their Nature and Formation", Information Systems Research, Vol. 23, No. 1, 2012, pp. 197-213.

Shapiro, C. and Varian, H. R., Information Rules, Harvard Business School Press, Boston, MA., 1999.

Szajna, B., "Empirical Evaluation of the Revised Technology Acceptance Model", Management Science, Vol. 42, No. 1, 1996, pp. 85-92.

Taylor, S. and Todd, P. A., “Assessing IT Usage: the Role of Prior Experience", MIS Quarterly, Vol. 19, No. 4, 1995, pp. 561-570.

Triandis, H. C., "Values, Attitudes, and
Interpersonal Behavior", In Nebraska Symposium on Motivation, 1979: Beliefs, Attitudes, and Values, (Page MM, Eds), pp, 195-25, University of Nebraska Press, Lincoln, NE., 1980.

Venkatesh, V. and Davis, F. D., “A Theoretical Extension of the Technology Acceptance Model: Four Longitudinal Field Studies”, Management Science, Vol. 46, No. 2, 2000, pp. 186-204.

Venkatesh, V., Morris, M. G., Davis, G. B., and Davis, F. D., "User Acceptance of Information Technology : Toward A Unified View”, MIS Quarterly, Vol. 27, No. 3, 2003, pp. 425-478.

Venkatesh, V., Thong, J. Y., Chan, F. K. Y., Hu, P. J-H., and Brown, S. A., "Extending the Two-Stage Information Systems Continuance Model: Incorporating UTAUT predictors and the Role of Context", Information Systems Journal, Vol. 21, 2011, pp. 527-555.

Venkatesh, V., Thong, J. Y., and Xu, X., "Consumer Acceptance and Use of Information Technology: Extending the Unified Theory of Acceptance and Use of Technology", MIS Quarterly, Vol. 36, No.1, 2012, pp. 157-178

Verplanken, B., "Beyond Frequency: Habit as Mental Construct", British Journal of Social Psychology, Vol. 45, 2006, pp. 639-656.

Verplanken, B. and Orbell, S., "Reflection on Past 
Behavior: A Self-Report Index of Habit

Strength", Journal of Applied Social

Psychology, Vol. 33, No. 6, 2003, pp.

1313-1330.

\section{이웅규(Lee, Woong-Kyu)}

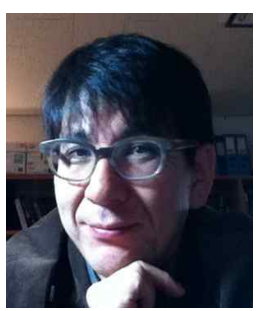

현재 대구대학교 경영학과 교수로 재직 중이다. KAIST 경 영대학에서 경영정보시스템 전 공으로 박사 학위를 취득하였 고, $\mathrm{KT}$ 선임연구원으로 근무하 였다. 주요 관심 분야는 정보기 술 수용과 전유(appropriation) 나자동사용 (automatic uses) 등과 같은 지속적 사용에 관련된 이슈 이외에도 switching costs, habits, attachment 등과 같이 새로운 기술로의 전환과 관련한 이슈다. 최근에는 정보기술과 디자인에 관련된 expressive values에 관심을 가지고 있다. Behaviour \& Information Technology를 비롯한 국내외 주요 저널에 논문을 게재하였고 정보시스템 연구의 편집위원장을 역임했고 현재는 ISR 편집위원장을 맡고 있다.

\section{김효정 (Hyo-Jung Kim)}

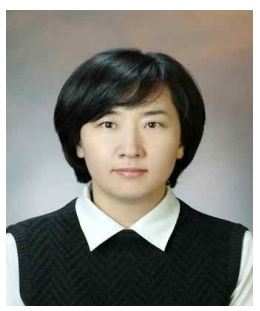

계명대학교 경영정보학과 박사과정을 졸업하였다. 경북 대학교 $\mathrm{BK}$ 연구교수로 재직하 였으며, 현재 계명대학교 교양 교육대학 정보화교육 조교수로 재직 중이다. 주요 관심분야는 IT Performance of Small Firms, e-Learning, Social Network Service, The Effect of On-Line Agent, m-Commerce, Information ethics 등이 다. 
「정보시스템연구」제22권 제1호, 2013년 3월

$<$ Appendix 1> Psychometric measures of the inexperienced group

\begin{tabular}{|c|c|c|c|c|c|}
\hline \multicolumn{2}{|c|}{ Construct } & Item & Loading & Standard error & t-value \\
\hline \multirow[t]{7}{*}{ Habit } & \multirow{7}{*}{$\begin{array}{l}\mathrm{AVE}=0.5423 \\
\mathrm{CR}=0.892\end{array}$} & HA1 & 0.684 & 0.0903 & 7.5708 \\
\hline & & HA2 & 0.7175 & 0.0763 & 9.4013 \\
\hline & & HA3 & 0.7835 & 0.0738 & 10.6172 \\
\hline & & HA4 & 0.7557 & 0.0675 & 11.1875 \\
\hline & & HA5 & 0.7057 & 0.0829 & 8.5136 \\
\hline & & HA6 & 0.8115 & 0.0416 & 19.4835 \\
\hline & & HA7 & 0.6873 & 0.0868 & 7.9161 \\
\hline \multirow[t]{4}{*}{ Intention } & \multirow{4}{*}{$\begin{array}{l}\text { AVE }=0.9092 \\
\mathrm{CR}=0.9756\end{array}$} & INT1 & 0.9443 & 0.013 & 72.7595 \\
\hline & & INT2 & 0.9491 & 0.0105 & 90.573 \\
\hline & & INT3 & 0.9651 & 0.0078 & 123.7559 \\
\hline & & INT4 & 0.9554 & 0.0086 & 111.2558 \\
\hline \multirow[t]{6}{*}{ Ease of use } & \multirow{6}{*}{$\begin{array}{l}\text { AVE }=0.7686 \\
\mathrm{CR}=0.9521\end{array}$} & EU1 & 0.7959 & 0.0353 & 22.5304 \\
\hline & & EU2 & 0.8552 & 0.0321 & 26.661 \\
\hline & & EU3 & 0.879 & 0.0277 & 31.7155 \\
\hline & & EU4 & 0.8846 & 0.0343 & 25.7637 \\
\hline & & EU5 & 0.9153 & 0.0206 & 44.4473 \\
\hline & & EU6 & 0.9241 & 0.0139 & 66.5308 \\
\hline \multirow[t]{6}{*}{ Usefulness } & \multirow{6}{*}{$\begin{array}{l}\text { AVE }=0.7183 \\
\mathrm{CR}=0.9386\end{array}$} & PU1 & 0.8529 & 0.0297 & 28.6766 \\
\hline & & PU2 & 0.8452 & 0.0389 & 21.7169 \\
\hline & & PU3 & 0.8729 & 0.0343 & 25.4574 \\
\hline & & PU4 & 0.8437 & 0.0294 & 28.6755 \\
\hline & & PU5 & 0.8326 & 0.0317 & 26.2746 \\
\hline & & PU6 & 0.8372 & 0.031 & 26.9815 \\
\hline
\end{tabular}

AVE: Average variance extracted, CR: Composite reliability

$<$ Appendix 2> Psychometric measures of the experienced group

\begin{tabular}{|c|c|c|c|c|c|}
\hline \multicolumn{2}{|c|}{ Construct } & Item & Loading & Standard error & $\mathrm{t}$-value \\
\hline \multirow[t]{7}{*}{ Habit } & \multirow{7}{*}{$\begin{array}{c}\mathrm{AVE}=0.6591 \\
\mathrm{CR}=0.9298\end{array}$} & HA1 & 0.8563 & 0.0521 & 16.4232 \\
\hline & & HA2 & 0.8867 & 0.0295 & 30.0657 \\
\hline & & HA3 & 0.9066 & 0.028 & 32.3344 \\
\hline & & HA4 & 0.8864 & 0.0342 & 25.9425 \\
\hline & & HA5 & 0.5634 & 0.1299 & 4.3377 \\
\hline & & HA6 & 0.8199 & 0.0829 & 9.8886 \\
\hline & & HA7 & 0.7049 & 0.1068 & 6.6025 \\
\hline \multirow[t]{4}{*}{ Intention } & \multirow{4}{*}{$\begin{array}{c}\mathrm{AVE}=0.7601 \\
\mathrm{CR}=0.9265\end{array}$} & INT1 & 0.8999 & 0.0199 & 45.183 \\
\hline & & INT2 & 0.9043 & 0.0207 & 43.5797 \\
\hline & & INT3 & 0.9151 & 0.0208 & 43.9963 \\
\hline & & INT4 & 0.7585 & 0.0538 & 14.106 \\
\hline \multirow[t]{6}{*}{ Ease of use } & \multirow{6}{*}{$\begin{array}{c}\mathrm{AVE}=0.6145 \\
\mathrm{CR}=0.9052\end{array}$} & EU1 & 0.784 & 0.0494 & 15.8656 \\
\hline & & EU2 & 0.7787 & 0.0586 & 13.2861 \\
\hline & & EU3 & 0.8191 & 0.0696 & 11.7635 \\
\hline & & EU4 & 0.7811 & 0.0848 & 9.2059 \\
\hline & & EU5 & 0.723 & 0.1047 & 6.9077 \\
\hline & & EU6 & 0.814 & 0.0614 & 13.2581 \\
\hline \multirow[t]{6}{*}{ Usefulness } & \multirow{6}{*}{$\begin{array}{c}\text { AVE }=0.7262 \\
\mathrm{CR}=0.9407\end{array}$} & PU1 & 0.8999 & 0.022 & 40.8722 \\
\hline & & PU2 & 0.8689 & 0.0239 & 36.2985 \\
\hline & & PU3 & 0.8816 & 0.0256 & 34.4265 \\
\hline & & PU4 & 0.8572 & 0.0306 & 28.0222 \\
\hline & & PU5 & 0.8129 & 0.0443 & 18.3483 \\
\hline & & PU6 & 0.7869 & 0.04 & 19.6863 \\
\hline
\end{tabular}

AVE: Average variance extracted, CR: Composite reliability 
$<$ Appendix $3>$ Correlations and average variance extracted of the inexperienced group

\begin{tabular}{|c|c|c|c|c|}
\hline & Habit & Intention & PEOU & PU \\
\hline Habit & 0.7364 & 0.0000 & 0.0000 & 0.0000 \\
\hline Intention & -0.4879 & 0.9535 & 0.0000 & 0.0000 \\
\hline PEOU & -0.3175 & 0.6264 & 0.8767 & 0.0000 \\
\hline PU & -0.4183 & 0.7248 & 0.6907 & 0.8475 \\
\hline
\end{tabular}

Shaded diagonals: squared root of AVE in each construct

$<$ Appendix $4>$ Correlations and average variance extracted of the experienced group

\begin{tabular}{|c|c|c|c|c|}
\hline & Habit & Intention & PEOU & PU \\
\hline Habit & 0.8118 & 0.0000 & 0.0000 & 0.0000 \\
\hline Intention & 0.0355 & 0.8718 & 0.0000 & 0.0000 \\
\hline PEOU & 0.2957 & 0.2742 & 0.7839 & 0.0000 \\
\hline PU & 0.3153 & 0.5963 & 0.4489 & 0.8522 \\
\hline
\end{tabular}

Shaded diagonals: squared root of AVE in each construct

<Appendix 5> Loadings and cross-loadings of the inexperienced group

\begin{tabular}{|c|c|c|c|c|}
\hline & Habit & Intention & PEOU & PU \\
\hline HA1 & 0.684 & -0.0707 & -0.0488 & -0.1464 \\
\hline HA2 & 0.7175 & -0.1329 & -0.1065 & -0.1356 \\
\hline HA3 & 0.7835 & -0.2254 & -0.2009 & -0.2628 \\
\hline HA4 & 0.7557 & -0.2611 & -0.1801 & -0.2517 \\
\hline HA5 & 0.7057 & -0.6253 & -0.402 & -0.4465 \\
\hline HA6 & 0.8115 & -0.4753 & -0.2559 & -0.3813 \\
\hline HA7 & 0.6873 & -0.1354 & -0.0997 & -0.1976 \\
\hline INT1 & -0.495 & 0.9443 & 0.6138 & 0.6854 \\
\hline INT2 & -0.476 & 0.9491 & 0.5716 & 0.6488 \\
\hline INT3 & -0.4483 & 0.9651 & 0.5897 & 0.7411 \\
\hline INT4 & -0.4433 & 0.9554 & 0.6134 & 0.6846 \\
\hline EU1 & -0.2783 & 0.544 & 0.7959 & 0.6146 \\
\hline EU2 & -0.2368 & 0.4463 & 0.8552 & 0.5867 \\
\hline EU3 & -0.2803 & 0.4952 & 0.879 & 0.5932 \\
\hline EU4 & -0.2381 & 0.4779 & 0.8846 & 0.5249 \\
\hline EU5 & -0.2965 & 0.5771 & 0.9153 & 0.5826 \\
\hline EU6 & -0.3228 & 0.7026 & 0.9241 & 0.7015 \\
\hline PU1 & -0.2652 & 0.57 & 0.6313 & 0.8529 \\
\hline PU2 & -0.3352 & 0.5118 & 0.5514 & 0.8452 \\
\hline PU3 & -0.2752 & 0.5188 & 0.532 & 0.8729 \\
\hline PU4 & -0.3805 & 0.659 & 0.5431 & 0.8437 \\
\hline PU5 & -0.4205 & 0.628 & 0.5793 & 0.8326 \\
\hline PU6 & -0.4198 & 0.7449 & 0.6509 & 0.8372 \\
\hline & & & & \\
\hline & & & \\
\hline
\end{tabular}


「정보시스템연구」제22권 제1호, 2013년 3월

<Appendix 6> Loadings and cross-loadings of the experienced group

\begin{tabular}{|c|c|c|c|c|}
\hline & Habit & Intention & PEOU & PU \\
\hline HA1 & 0.8563 & 0.0697 & 0.2209 & 0.3221 \\
\hline HA2 & 0.8867 & -0.0291 & 0.2882 & 0.244 \\
\hline HA3 & 0.9066 & 0.0728 & 0.2504 & 0.3224 \\
\hline HA4 & 0.8864 & 0.0403 & 0.2896 & 0.2817 \\
\hline HA5 & 0.5634 & 0.1323 & 0.0957 & 0.1711 \\
\hline HA6 & 0.8199 & -0.0512 & 0.2533 & 0.2258 \\
\hline HA7 & 0.7049 & 0.0024 & 0.2374 & 0.1883 \\
\hline INT1 & 0.0388 & 0.8999 & 0.1891 & 0.6003 \\
\hline INT2 & -0.0419 & 0.9043 & 0.1957 & 0.5270 \\
\hline INT3 & 0.0536 & 0.9151 & 0.2991 & 0.4918 \\
\hline INT4 & 0.0822 & 0.7585 & 0.2944 & 0.4406 \\
\hline EU1 & 0.2858 & 0.2255 & 0.784 & 0.3438 \\
\hline EU2 & 0.2182 & 0.3208 & 0.7787 & 0.5897 \\
\hline EU3 & 0.1736 & 0.1555 & 0.8191 & 0.2481 \\
\hline EU4 & 0.2417 & 0.0446 & 0.7811 & 0.1627 \\
\hline EU5 & 0.1676 & 0.1272 & 0.7230 & 0.1251 \\
\hline EU6 & 0.2680 & 0.233 & 0.8140 & 0.3098 \\
\hline PU1 & 0.3558 & 0.4985 & 0.3765 & 0.8999 \\
\hline PU2 & 0.3401 & 0.4450 & 0.3571 & 0.8689 \\
\hline PU3 & 0.1722 & 0.5451 & 0.3332 & 0.8816 \\
\hline PU4 & 0.1774 & 0.4974 & 0.3247 & 0.8572 \\
\hline PU5 & 0.1769 & 0.5276 & 0.3444 & 0.8129 \\
\hline PU6 & -0.4198 & 0.7449 & 0.6509 & 0.8372 \\
\hline & & & & \\
\hline & & & & \\
\hline
\end{tabular}


<국문요약>

\title{
기존 시스템 사용 습관과 새로운 시스템 수용과의 관계
}

\author{
이웅규·김효정
}

새로운 시스템의 수용은 대부분의 경우 유용성이나 사용용이성과 같은 이성적인 평가와 함께 기존 시스템 사용에 대한 무의식적인 습관에 따라 결정된다. 흥미롭게도 기존 시스템에 대한 습관의 효과는 상이한 방향을 가질 수 있다. 어떤 경우에는 전환비용 때문에 부정적이 될 수도 있지만 어떤 경우에는 현 시스템에 대한 풍부한 경험 때문에 긍정적인 효과를 보일 수도 있다. 본 연구에서는 기존 시스템에 대한 습관과 새로운 시스템에 대한 판단 간의 관계가 새로운 시스템에 대한 직접 경험에 따라 달라질 수 있음을 가설로 제시하였다. 즉, 새로운 시스템에 대한 경험이 없으면 부정적인 관계가 되겠지만 경험이 있는 경우에는 긍정적인 관계가 될 수도 있다. 이 가설들에 대한 타당성을 보여 주기 위해 168 명의 우리나라 대학생들을 대상으로 실증적 검증을 하였다. 수용 대상은 구글 닥스(Google Docs) 이었고 조사에 참여한 학생들은 이전에 구글 닥스에 대한 경험을 가지고 있지 않았다. 조사 참여자 전부에게 구글 닥스에 대한 특성을 설명한 뒤 임의로 두 그룹으로 나눈 다음 한 그룹은 구글 닥스를 실제 사용할 기회를 주었고 다른 그룹에게는 주지 않았다. 결과적으로 경험을 한 그룹은 기존 시스템 에 대한 습관과 새로운 시스템에 대한 주관적 판단 간에 부정적인 관계를 보인 반면 경험이 없는 그룹은 긍정적인 관계를 보였다.

Keywords: habit, IT adoption or acceptance, experience, switching cost

* 이 논문은 2012년 9월 24일 접수하여 2차 수정을 거쳐 2013년 1월 9일 게재 확정되었습니다. 